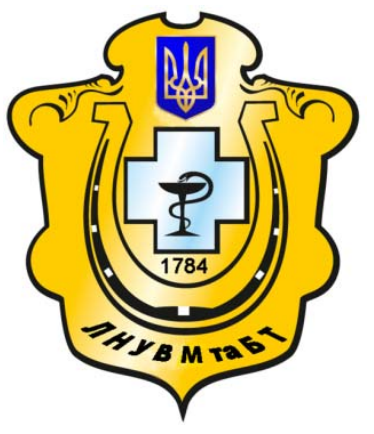

Науковий вісник Львівського національного університету ветеринарної медицини та біотехнологій імені С.3. Гжицького

Scientific Messenger of Lviv National University of Veterinary Medicine and Biotechnologies named after S.Z. Gzhytskyj

doi:10.15421/nvlvet7007

ISSN 2413-5550 print

ISSN 2518-1327 online

$\underline{\text { http://nvlvet.com.ua/ }}$

\title{
УДК 619:616.98:636.8 \\ Деякі макроскопічні зміни у внутрішніх органах котів, що загинули від каліцивірусної інфекції
}

\author{
С.С. Гаркуша, А.Я. Плагун \\ stas_grin@mail.ru \\ Національний університет біоресурсів і природокористування Украӥни, \\ вул. Героїв Оборони, 15, м. Київ, 03041, Украӥна
}

\begin{abstract}
В літературних джерелах досить повно описано етіологію, патогенез, клінічну картину та лікування даної хвороби, а от патолого-анатомічні зміни, описані досить поверхнево. Зокрема з макроскопічних змін при каліцииірусній інфекціі більшість авторів описують кон'юнктивіт, стоматит та пневмонію. Метою даної роботи було більш детально вивчити макроскопічні зміни у внутрішніх органах котів різних вікових груп та порід, щуо загинули від каліцивірусної інфекції. Для досягнення даної мети були поставлені наступні задання, а саме: провести патолого-анатомічний розтин котів при каліиивірусній інфекиії, вивчити макроскопічні зміни у внутрішніх органах котів за даної хвороби та детально описати макроскопічні зміни у внутрішніх органах котів, щчо раніше не описувались.

Матеріалом для дослідження слугували трупи 5 кішок різного віку, щзо загинули від каліиивірусної інфекиії. Патологоанатомічний розтин трупів котів виконували методом часткової евісцерації на кафедрі патологічної анатомії Національного університету біоресурсів і природокористування Украӥни.

При патолого-анатомічному розтині в котів, щзо загинули від каліцивірусної інфекиї було встановлено: катаральний кон'юнктивіт, гострий катаральний риніт, стоматит, глосит, набряк і серозний та серозно-геморагічний лімфаденіт, а також венозний застій та набряк легень, печінка гіперемійована, мускатна. Спостерігали міогенну дилатацію серия та катаральний дуоденіт.

Ключові слова: патолого-анатомічний розтин, коти, тимус, легені, серие, нирки, селезінка, лімфатичні вузли, судина.
\end{abstract}

\section{Некоторые макроскопические изменения во внутренних органах котов по- гибших от калицивирусной инфекции}

\author{
С.Е. Гаркуша, А.Я. Плагун \\ stas_grin@mail.ru
}

Наџиональный университет биоресурсов и природопользования Украины, ул. Героев Обороны, 15, г. Киев, 03041, Украина

В литературных источниках достаточно полно описано этиологию, патогенез, клиническую картину и лечение данной болезни, а патологоанатомические изменения описаны достаточно поверхностно. В частности с макроскопических изменений при калицивирусной инфекции большинство авторов описывают конъюнктивит, стоматит и пневмонию. Целью данной работь было более детально изучить макроскопические изменения во внутренних органах котов разных возрастных групп и пород, погибших от калицивирусной инфекции. Для достижения данной иели были поставлены следуюшие задания, а именно: провести патолого-анатомическое вскрытие котов при калицивирусной инфекиии, изучить макроскопические изменения во внутренних органах котов в данной болезни и подробно описать макроскопические изменения во внутренних органах котов, ранее не описывались.

Материалом для исследования послужили трупь 5 кошек разного возраста, погибших от калищивирусной инфекции. Патологоанатомическое вскрытие трупов кошек выполняли методом частичной эвисиерации на кафедре патологической анатомии

Citation:

Garkusha, S.E., Plagun, A.J. (2016). Some macroscopic changes in internal organs cats died from calicivirus infection. Scientific Messenger LNUVMBT named after S.Z. Gzhytskyj, 18, 3(70), 30-32. 
Национального университета биоресурсов и природопользования Украиныл.

При патологоанатомическом вскрытии у котов, погибиих от калицивирусной инфекции установлено катаральньй конъюнктивит, острый катаральный ринит, стоматит, глоссит, отек и серозньій и серозно-геморрагический лимфаденит, а также венозный застой и отек легких, печень гиперемирована, мускатная. Наблюдали миогенную дилатацию сердияа и катаральньй дуоденит.

Ключевые слова: патологоанатомическое вскрытие, коты, тимус, легкие, сердие, почки, селезенка, лимфатические узль, соcyd.

\title{
Some macroscopic changes in internal organs cats died from calicivirus infection
}

\author{
S.E. Garkusha, A.J. Plagun \\ stas_grin@mail.ru \\ National university of life and environmental sciences of Ukraine, \\ Heroyiv Oborony Str., 11, Kyiv, 03041, Ukraine
}

Calicivirus infection of cats is a highly contagious disease of animals of the cat family, which is clinically manifested by conjunctivitis, ulcerative stomatitis, rhinitis, tracheobronchitis, pneumonia, and accompanied by significant mortality. This infection is widespread in populations of domestic and wild felines throughout the world.

According to modern world literature the manifestation of the disease depends on the strain of the pathogen. Depending on the strain infected with caliciviruses studs in some cases can be clinically healthy, others have ulcers on the mucous membranes of the oral cavity and the symptoms are not much pronounced pneumonia. Less frequently recorded disease that is accompanied by lameness, abortions and severe pneumonia. However, the death of all forms recorded very rarely. According to many authors media avirulence and weakly virulent strains calicivirus of infection is $36 \%$ of cats.

However, in the last decade were also recorded epizootics of severe disease, mortality is up to $50 \%$. Clinically the disease was characterized by oppression, high continued fever, anorexia, edema of face and extremities, with lesions of dermatitis or alopecia on the face, ears and distal parts of the limbs. In the literature adequately described the etiology, pathogenesis, clinical presentation, and treatment of this disease, and pathological changes are described is not complete. In particular macroscopic changes at calicivirus infection, most authors describe conjunctivitis, stomatitis and pneumonia. The aim of this study was to examine in more detail the macroscopic changes in the internal organs of cats of various ages and breeds, died of calicivirus infection. the following tasks were set to achieve this goal, namely to carry out post-mortem dissection of cats with calicivirus infection to study the macroscopic changes in the internal organs in cats this disease and in detail describe the macroscopic changes in the internal organs of cats, not previously described.

The material for the study were the corpses of five cats of various ages, who died of calicivirus infection. Autopsy corpses of cats was performed by partial evisceration at the Department of Pathological Anatomy of the National University of Life and Environmental Sciences of Ukraine. At postmortem autopsy in cats killed by calicivirus infection indicate catarrhal conjunctivitis, acute catarrhal rhinitis, stomatitis, glossitis, edema and serous and serosanguineous lymphadenitis, and venous congestion and pulmonary edema, liver hyperemia, Muscat. Observed myogenic dilatation of the heart and catarrhal duodenitis.

Key words: mortem autopsy, cats, thymus, lungs, heart, kidneys, spleen, lymph nodes, the vessel.

\section{Вступ}

Важко спостерігати за хворобливим станом улюбленого котика. Хочеться захистити його від усіх на світі вірусів, але деякі 3 них дуже підступні, тому небезпека може чекати на кожному кроці (Tilli and Smit, 2001).

За останні роки в нашій країні значно зріс інтерес до розведення кішок. Утримання кішок в домашніх умовах, а також створення розплідників, проведення виставок створюють передумови до виникнення i розповсюдження хвороб (Korotkonozhkina, 2003). Однією $з$ таких хвороб є каліцивірусна інфекція. Каліцивірусна інфекція широко поширена в усьому світі, зокрема і в Україні. В літературних джерелах досить повно описано етіологію, патогенез, клінічну картину та лікування даної хвороби, а от патолого-анатомічні зміни, описані не повно. Зокрема 3 макроскопічних змін при каліцивірусній інфекції більшість авторів описують кон'юнктивіт, стоматит та пневмонію (Rahmanina et al., 1994; Tilli and Smit, 2001).

Метою даної роботи було більш детально вивчити макроскопічні зміни у внутрішніх органах котів різних вікових груп та порід, що загинули від каліци- вірусної інфекції. Для досягнення даної мети були поставлені наступні задання: провести патологоанатомічний розтин котів при каліцивірусній інфекції, вивчити макроскопічні зміни у внутрішніх органах котів за даної хвороби та детально описати макроскопічні зміни у внутрішніх органах котів що раніше не описувались.

\section{Матеріал і методи досліджень}

Матеріалом для дослідження слугували трупи 5 кішок різного віку, що загинули від каліцивірусної інфекції. Патолого-анатомічний розтин трупів виконували методом часткової евісцерації (Goral's'kyj et al., 2005; Zon et al., 2009) на кафедрі патологічної анатомії Національного університету біоресурсів i природокористування України.

\section{Результати та їх обговорення}

При зовнішньому огляді трупів тварин виявили наступне: вгодованість всіх тварин, була середньою або вище середньої. При огляді органів голови та шиї: кон'юнктива очей набрякла, волога, спостерігали гіперемію судин кон'юнктиви в 2-х кошенят ексудат 
повністю склеював повіки. Слизова оболонка носа набрякла, вкрита мутним серозно-слизистим ексудатом, який витікав із носових ходів і засихав в вигляді великих кірок на губах і шерсті навколо них.

При огляді ротової порожнини на слизовій оболонці відзначали добре виражені крововиливи, ерозії і виразки, головним чином, на внутрішній поверхні губ, на яснах в ділянці корінних зубів і в одному випадку на спинці язика. В усіх тварин, які загинули від каліцивірусної інфекції, реєстрували набряк і гіперемію мигдаликів. Заглоткові, підщелепові, поверхневі та глибокі шийні лімфатичні вузли були збільшені в розмірах, набряклі, з поверхні почервонілі, на розрізі гіперемійовані, соковиті.

Кровоносні судини між кільцями трахеї були розширені, переповнені кров'ю. В просвіті трахеї виявляли пінисту рідину білувато-рожевого кольору.

У 4-х тварин легені при проведенні макроскопічних досліджень були вологими, блискучими, нерівномірно забарвленими (чергувалися ділянки рожевого, червоного кольору) та мали тістувату консистенцію. Судини кровонаповненні. 3 поверхні розрізу стікала піниста рідина. Шматочок легень або важко плавав у воді, або тонув. Найбільш виразні зміни спостерігались в ділянках легень які безпосередньо прилягали до діафрагми.

Серце у всіх тварин було рожево-червоного кольору з сіруватим відтінком. Міокард в'ялої консистенції. Стінка правого шлуночка нависала над поздовжньої борозною, співвідношення товщини правого і лівого шлуночків - 1:5. Кровоносні судини серця були виразно розширені, переповнені кров’ю. В усіх камерах серця виявляли темно-червону згорнуту кров.

Всі лімфатичні вузли грудної порожнини збільшені та почервонілі, на розрізі соковиті.

У дванадцятипалій кишці у 3 з 5 кішок відзначали гіперемію та набряк слизової оболонки.

Печінка в більшості випадків (у 4-х котів) була нерівномірно забарвлена - 3 ділянками сіруватожовтого, блідо-жовтого або яскраво-жовтого кольору, на багатьох ділянках мускатна, місцями виразно гіперемійована. На розрізі малюнок печінкових часточок був помітно підкресленим. У одного кота вся печінка мала жовтуватий колір з ділянками гіперемії.

У підшлунковій залозі виявляли неоднорідність забарвлення (чергування ділянок жовто-рожевого і червоного кольору), набрякла, збільшена в розмірах, поверхня розрізу була волога у 2 кішок відзначали крововилив під капсулою.

В усіх загиблих від каліцивірусної інфекції котів нирки мали сірувато-коричнюватий колір, а місцями - ділянки жовтуватого і червонуватого кольору. Всі кровоносні судини були виразно розширені, переповнені кров'ю. На розрізі кіркова і мозкова речовини нирок вологі, межа між кірковим і мозковим шарами була досить чітка. Кіркова речовина - коричневого кольору, з дрібними крововиливами, мозкова - нерівномірно рожева.

При макроскопічному дослідженні надниркової залози виявлено неоднорідність фарбування органу (колір з поверхні варіював від світло-коричневого до червоно-синього); горбисту поверхню, наявність округлих вузликів діаметром 1-3 мм, що піднімаються над поверхнею органу.

\section{Висновки}

При патолого-анатомічному розтині в котів, що загинули від каліцивірусної інфекції було встановлено: катаральний кон'юнктивіт, гострий катаральний риніт, стоматит, глосит, набряк і серозний та серозногеморагічний лімфаденіт, а також венозний застій та набряк легень, печінка гіперемійована, мускатна. Спостерігали міогенну дилятацію серця та катаральний дуоденіт.

Перспективи подальших досліджень. Провести гістологічні дослідження внутрішніх органів котів різних вікових груп, що загинули від каліцивірусної інфекції.

\section{Бібліографічні посилання}

Goral's'kyj, L.P., Homych, V.T., Konons'kyj, O.I. (2005). Osnovy gistologichnoi' tehniky i morfofunkcional'ni metody doslidzhennja u normi ta pry patologii'. Zh.: «Polissja» (in Ukrainian).

Zon, G.A., Skrypka, M.V., Ivanovs'ka, L.B. (2009). Patologoanatomichnyj roztyn tvaryn: Navchal'nyj posibnyk. Donec'k, PP Glazunov R.O. (in Ukrainian).

Tilli, L., Smit, F. (2001). Veterynarija. Hvoroby kishok ta sobak. M.: «GEOTAR-MED» (in Russian).

Korotkonozhkina, O. (2003). Kalicivirusnaja infekcija koshek. Tvoja koshka. 3, 14-16 (in Ukrainian).

Rahmanina, M.M., Jelizbarashvili, Je.I., Urasov, V.I. i dr. (1994). Kaliciviroz koshek. Veterinarija. 9, 51-53 (in Russian).

Стаття надійшла до редакиії 28.09.2016 